\title{
Investigation of metals content in the fine fraction of municipal waste from Alytus Regional Landfill
}

Rugilè Kemeklytė,

\author{
Algimantas Bučinskas*, \\ Gintaras Denafas \\ Department of Environmental Technology, \\ Faculty of Chemical Technology, \\ Kaunas University of Technology, \\ 19 Radvilenu Road, \\ 50524 Kaunas, Lithuania
}

\begin{abstract}
This study presents the results of investigation of the fine waste fraction from the Alytus Regional Landfill. The fine fraction was analysed with the aim of characterization of the chemical elements content using scanning electron microscopy, coupled with energy-dispersive spectroscopy (EDS), SEM and X-ray diffraction (XRD) analysis. Quartz $\mathrm{SiO}_{2}$, calcite $\mathrm{CaCO}_{3}$, anhydrite $\mathrm{CaSO}_{4}$, albite $\mathrm{NaAlSi}_{3} \mathrm{O}_{8}$, dolomite $\mathrm{CaMg}\left(\mathrm{CO}_{3}\right)_{2}$, microcline $\mathrm{KAlSi}_{3} \mathrm{O}_{8}$, periclase $\mathrm{MgO}$ and muscovite $\mathrm{KNa}(\mathrm{Al}, \mathrm{Mg}, \mathrm{Fe})_{2}\left(\mathrm{Si}_{3.1}\right.$, $\left.\mathrm{Al}_{0.9}\right) \mathrm{O}_{10}(\mathrm{OH})_{2}$ minerals were identified. The quantity of $\mathrm{C}, \mathrm{O}, \mathrm{Na}, \mathrm{Mg}, \mathrm{Al}$, $\mathrm{Si}, \mathrm{K}, \mathrm{Ca}, \mathrm{Fe}, \mathrm{P}, \mathrm{S}, \mathrm{Cl}$ and Ti chemical elements was determined and their percentage change after heating was calculated.
\end{abstract}

Keywords: fine fraction, landfill waste, SEM, EDS, XRD

\section{INTRODUCTION}

Recently, the lack of resources and the deterioration of the quality of ores have led to new ways of extracting the necessary raw materials. This has led to attempts of finding new ways of recovering valuable resources. One of such ways is recovering resources from landfills. Besides the possibility of energy recovery from the combustible (mainly coarse) fraction there is also an opportunity to extract metals, mainly from the fine fraction of landfills. Recently there have been several studies of metals content in this fraction. It was found that the concentration of critical major elements and rare earth elements (REEs) is significantly lower than in mining and secondary resources mono-landfills (industrial dump) areas; the concentration of such elements as $\mathrm{Fe}, \mathrm{Al}$, $\mathrm{Cu}, \mathrm{Pb}, \mathrm{Ni}$ and some other might become of interest for extraction in more or less near future [2, 3 , 10]. The fine fraction of waste (particle size ranging between $<10 \mathrm{~mm}$ and $<25.4 \mathrm{~mm}$ ) is $40-70 \%(\mathrm{w} / \mathrm{w})$ of mined landfill waste, and is typically considered

* Corresponding author. Email: algimantas.bucinskas@ktu.lt mainly soil containing varying amounts of landfilled materials [6, 8$]$. The fine fraction is the best source of metals in waste - [12] reported that $37-57 \%$ of heavy metals in the organic fraction of Municipal Solid Waste (MSW), including $\mathrm{Cd}, \mathrm{Cr}, \mathrm{Cu}, \mathrm{Hg}, \mathrm{Ni}, \mathrm{Pb}$ and $\mathrm{Zn}$, were concentrated in fine particles, which accounted for only $28 \%(\mathrm{~m} / \mathrm{m})$ of the total waste content. On the other hand, studies made on landfills with a high percentage of plastics and textiles show that under these conditions the fine materials are not the greatest fraction [11]. In [10] investigations of an open dump in Thailand, less than $18 \%$ of the material was smaller than $25 \mathrm{~mm}$, while $69 \%$ had a size bigger than $50 \mathrm{~mm}$.

The waste analysed in this article was obtained by drilling in the Alytus Regional Landfill [1].

In [5] using pyrometallurgical processes $\mathrm{Zn}$ and Mn recovery rates were $80.8-100 \%$ and $77.6-95.9 \%$, respectively, while the $\mathrm{Pb}$ recovery rate was only $0.68-3.14 \%$. It is worth mentioning [汭] that despite larger initial capital investments, the production cost using pyrometallurgy is lower than using hydrometallurgy or electrometallurgy. That is why we decided to investigate changes of crystallographic structures 
and metal content after heating of the samples at $550^{\circ} \mathrm{C}$ and $850^{\circ} \mathrm{C}$ temperature.

\section{EXPERIMENTAL}

\section{Fine fraction of municipal waste landfill}

The morphological composition of landfills was investigated experimentally by the method of drilling (Alytus) or excavation (Torma). Investigations were made according to the Standard Test Method for Determination of the Composition of Unprocessed Municipal Solid Waste (D 5231 - 92). In Alytus, three drillings were conducted with a $15 \mathrm{~cm}$ drill in specified parts of the 1 st section (which is operating from the year 2007 onwards. Later we will talk only about the 1st section) and waste samples were drawn every one meter between 1 and 10 meters in depth [4]. $285 \mathrm{~kg}$ was excavated in total. The waste was sorted into four size fractions of $>80 \mathrm{~mm}, 80$ $40 \mathrm{~mm}, 40-20 \mathrm{~mm}$, and $<20 \mathrm{~mm}$. The waste was classified into paper and cardboard, glass, textiles, soft plastics, hard plastics, medical and other noncombustible electronics, and fine fraction $(<20 \mathrm{~mm})$. The waste was dried at $105^{\circ} \mathrm{C}$ for two hours and then stored at room temperature in a desiccator. To get heated waste, it was heated using the muffle furnace SNOL $8.2 / 1100$ at $550^{\circ} \mathrm{C}$ and $850^{\circ} \mathrm{C}$ temperature, respectively, for two hours, afterwards it was stored in a desiccator at room temperature.

The fine fraction of the municipal waste landfill was investigated in three cases:
- unburned;

- heated at $550^{\circ} \mathrm{C}$ temperature;

- heated at $850^{\circ} \mathrm{C}$ temperature.

A ZEISS EVO MA10 scanning electron microscope equipped with a Bruker XFlash 6/10 EDX detector was used for chemical composition measurements of the fine waste fraction from the Alytus Regional Landfill. The x-ray diffraction patterns of the fine waste fraction from the Alytus Regional Landfill were recorded with a DRON6 diffractometer in the Bragg-Brentano configuration. The $\mathrm{CuKa}$ wavelength radiation (tube voltage of $30 \mathrm{kV}$ and current of $20 \mathrm{~mA}$ ) filtered with a flat diffracted beam pyrolitic graphite monochromator was used. Data were collected over the diffraction range $2 \theta=5-70^{\circ}$, with a step of $0.02^{\circ}$ and counting time of $1 \mathrm{~s}$ per step using a scintillation detector.

\section{RESULTS AND DISCUSSION}

\section{Unburned fine fraction}

X-ray diffraction analysis (XRD) was performed on unburned fine fraction samples taken from the landfill at 1, 2, 3, 5, 7 and 9 meters. The depths of 2, 5 and $9 \mathrm{~m}$ are characterized by minerals like quartz $\mathrm{SiO}_{2}$, calcite $\mathrm{CaCO}_{3}$, albite $\mathrm{NaAlSi}_{3} \mathrm{O}_{8}$, dolomite $\mathrm{CaMg}\left(\mathrm{CO}_{3}\right)_{2}$ and microcline $\mathrm{KAlSi}_{3} \mathrm{O}_{8}$. At depths of 1,3 and $7 \mathrm{~m}$, muscovite $\mathrm{KNa}(\mathrm{Al}, \mathrm{Mg}, \mathrm{Fe})_{2}\left(\mathrm{Si}_{3.1}, \mathrm{Al}_{0.9}\right)$ $\mathrm{O}_{10}(\mathrm{OH})_{2}$ was also found (Fig. 1).

For the determination of the amount of main and trace elements in the fine fraction of waste, the EDS

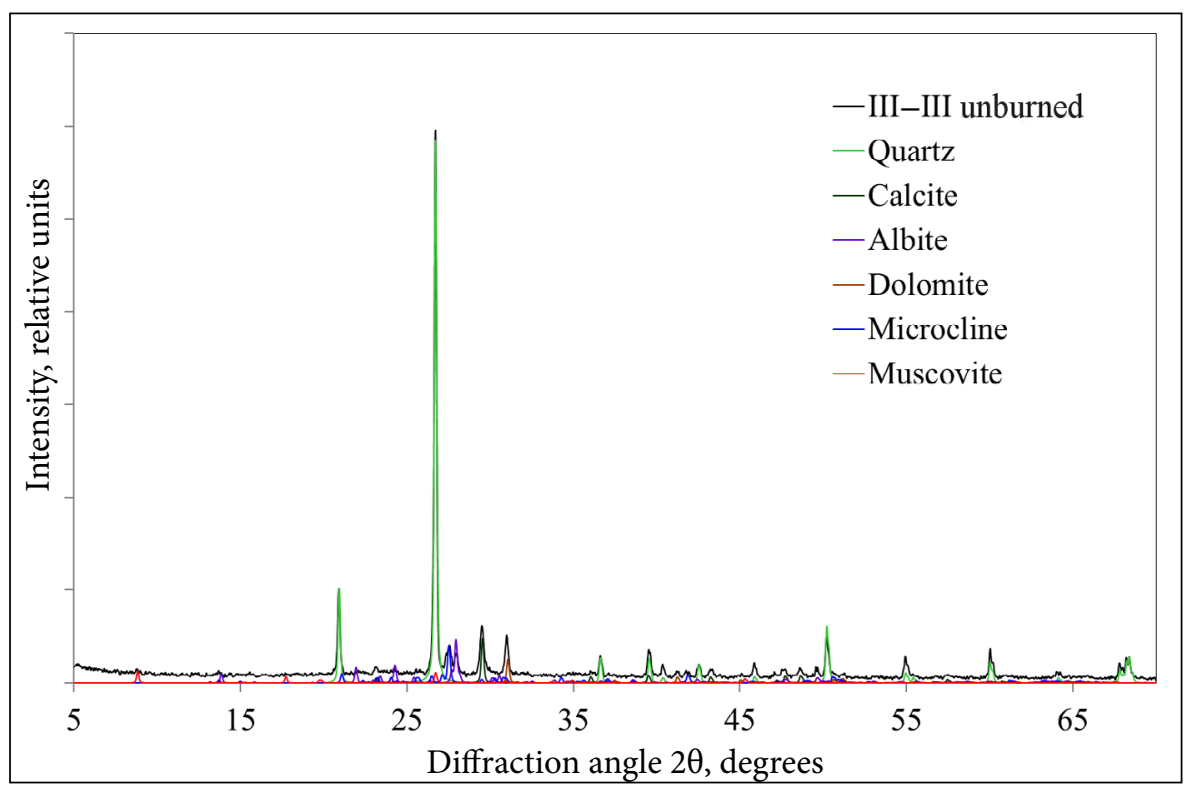

Fig. 1. XRD analysis of the unburned fine fraction at $3 \mathrm{~m}$ depth 
analysis method was applied. In the unburned fine fraction, elements such as chlorine $\mathrm{Cl}$, phosphorus $\mathrm{P}$ and titanium Ti have been identified in addition to the defined mineralogical modifications. This is true for all layers of the landfill at the depths of 1 , 2, 3, 5, 7 and $9 \mathrm{~m}$. The SEM micrograph shows that the unburned fine fraction is composed of different size crystals, the largest are around $20-60 \mu \mathrm{m}$ in size (Fig. 2). The EDS spectrum showed that the average amount of oxygen in all layers was 46.97 wt.\%, followed by carbon with $22.71 \mathrm{wt} . \%$, silicon accounted for $14.66 \mathrm{wt} . \%$, and calcium $8.24 \mathrm{wt} . \%$ (Table).

The oxygen amount little changes between different layers. Carbon is variating from $26.21 \mathrm{wt} . \%$ in the first layer, then as little as $19.34 \mathrm{wt} . \%$ in the 3rd layer, later increases and again decreases. The amount of silicon varies from $12.27 \mathrm{wt} . \%$ in the top layer to the maximum of $16.57 \mathrm{wt} . \%$ in the second layer. Calcium fluctuates a little, slowly decreasing from the top. By contraries, the amount of rest elements increases from top to bottom (Fig. 3).

\section{Heated at $550^{\circ} \mathrm{C}$ temperature fine fraction}

Quartz $\mathrm{SiO}_{2}$, calcite $\mathrm{CaCO}_{3}$, anhydrite $\mathrm{CaSO}_{4}$, albite $\mathrm{NaAlSi}_{3} \mathrm{O}_{8}$, dolomite $\mathrm{CaMg}\left(\mathrm{CO}_{3}\right)_{2}$, microcline $\mathrm{KAlSi}_{3} \mathrm{O}_{8}$ and muscovite $\mathrm{KNa}(\mathrm{Al}, \mathrm{Mg}, \mathrm{Fe})_{2}\left(\mathrm{Si}_{3.1}\right.$ $\left.\mathrm{Al}_{0.9}\right) \mathrm{O}_{10}(\mathrm{OH})_{2}$ were found in the heated at $550^{\circ} \mathrm{C}$ fine fraction (1, 2, 3 (Fig. 4), 7 and $9 \mathrm{~m}$ depths).
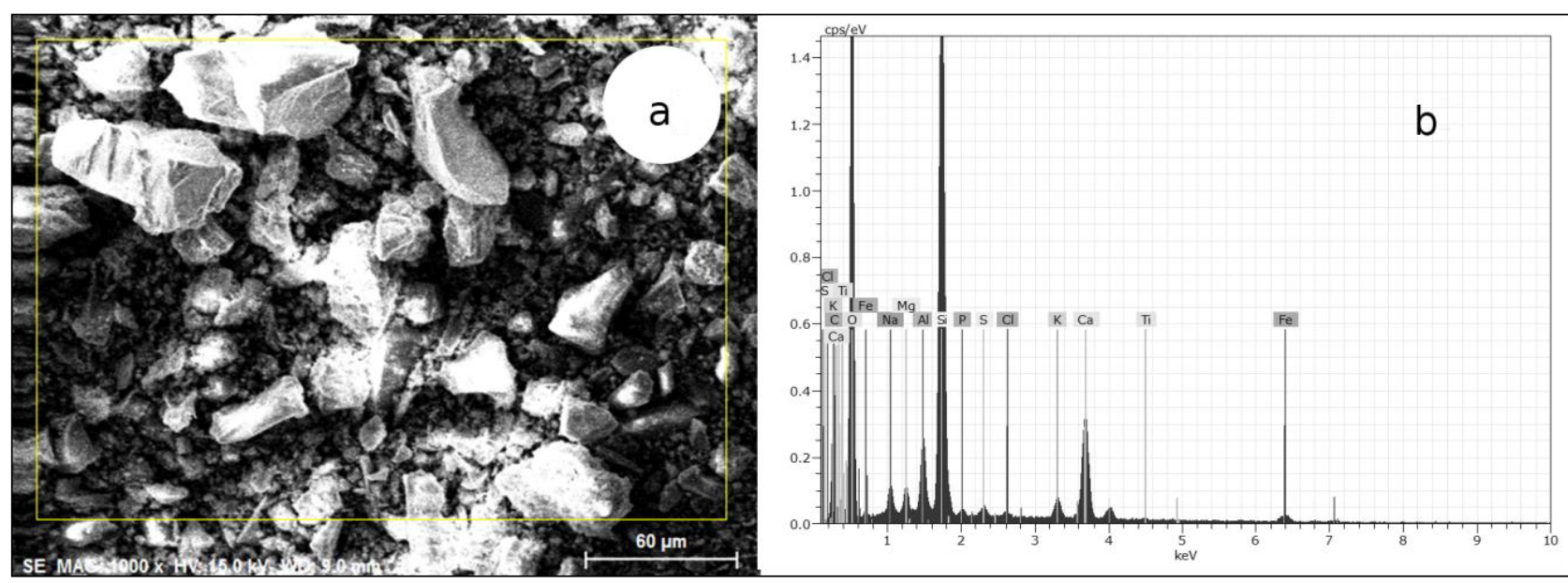

Fig. 2. Unburned fraction SEM under magnification of 1000 (a) and the EDS spectrum of the fine fraction (b) (3 m depth)

Table. Average amount of different elements in all landfill layers

\begin{tabular}{|c|c|c|c|c|c|c|}
\hline & $\begin{array}{l}\text { Unburned, } \\
\text { average, \% }\end{array}$ & $\begin{array}{c}550^{\circ} \mathrm{C} \text {, aver- } \\
\text { age, } \%\end{array}$ & $\begin{array}{c}850^{\circ} \mathrm{C} \text {, average, } \\
\%\end{array}$ & $\begin{array}{c}\% \text { change, un- } \\
\text { burned }->550^{\circ} \mathrm{C}\end{array}$ & $\begin{array}{c}\% \text { change, } \\
550^{\circ} \mathrm{C} \rightarrow 850^{\circ} \mathrm{C}\end{array}$ & $\begin{array}{l}\% \text { change, un- } \\
\text { burned }->850^{\circ} \mathrm{C}\end{array}$ \\
\hline Carbon & 22.71 & 7.20 & 3.06 & $-68 \%$ & $-58 \%$ & $-87 \%$ \\
\hline Oxygen & 46.97 & 47.46 & 46.38 & $1 \%$ & $-2 \%$ & $-1 \%$ \\
\hline Sodium & 0.85 & 0.88 & 1.26 & $4 \%$ & $43 \%$ & $49 \%$ \\
\hline Magnesium & 0.67 & 0.95 & 1.49 & $42 \%$ & $57 \%$ & $122 \%$ \\
\hline Aluminum & 1.88 & 2.59 & 3.26 & $38 \%$ & $26 \%$ & $73 \%$ \\
\hline Silicon & 14.66 & 18.63 & 21.06 & $27 \%$ & $13 \%$ & $44 \%$ \\
\hline Potassium & 1.24 & 2.06 & 1.71 & $67 \%$ & $-17 \%$ & $38 \%$ \\
\hline Calcium & 8.24 & 13.85 & 16.29 & $68 \%$ & $18 \%$ & $98 \%$ \\
\hline Iron & 1.96 & 3.92 & 3.42 & $100 \%$ & $-13 \%$ & $75 \%$ \\
\hline Phosphorus & 0.07 & 0.29 & 0.33 & $291 \%$ & $16 \%$ & $355 \%$ \\
\hline Sulfur & 0.46 & 1.31 & 0.98 & $188 \%$ & $-25 \%$ & $115 \%$ \\
\hline Chlorine & 0.20 & 0.46 & 0.39 & $134 \%$ & $-15 \%$ & $100 \%$ \\
\hline Titanium & 0.11 & 0.40 & 0.37 & $270 \%$ & $-8 \%$ & $242 \%$ \\
\hline
\end{tabular}




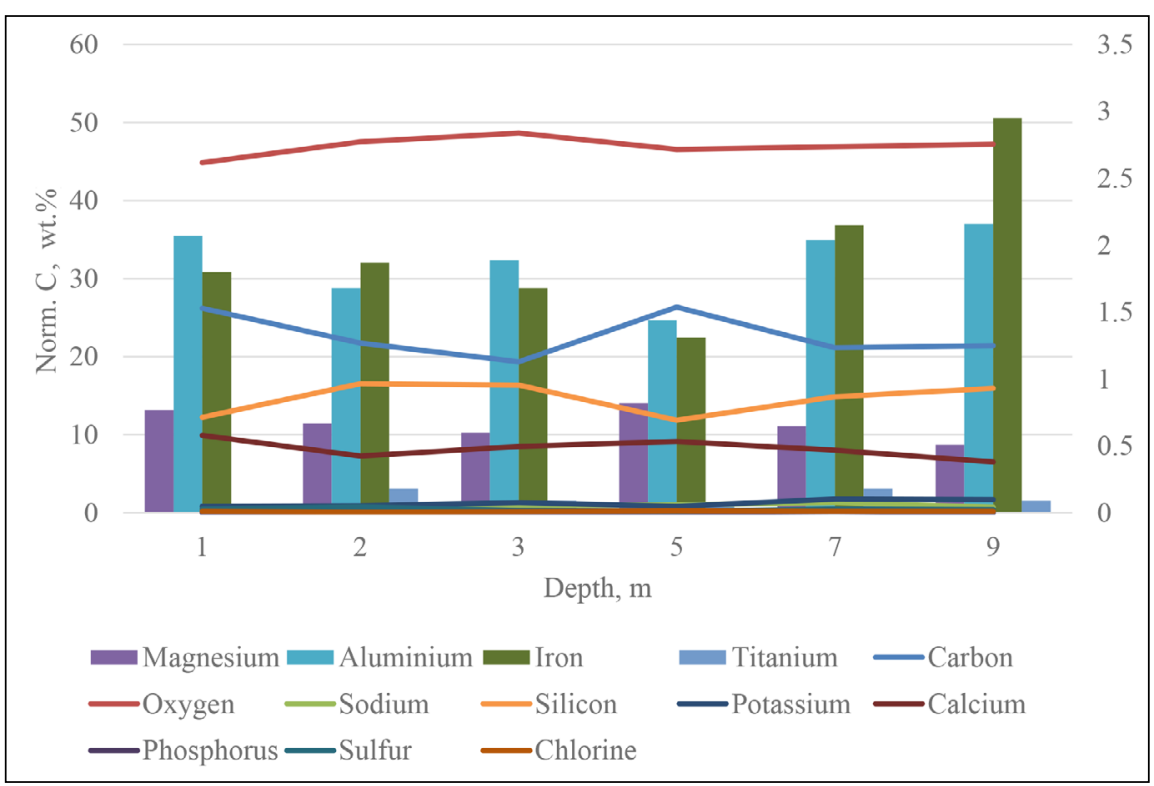

Fig. 3. Changes of the unburned fine fraction elemental composition in different landfill layers

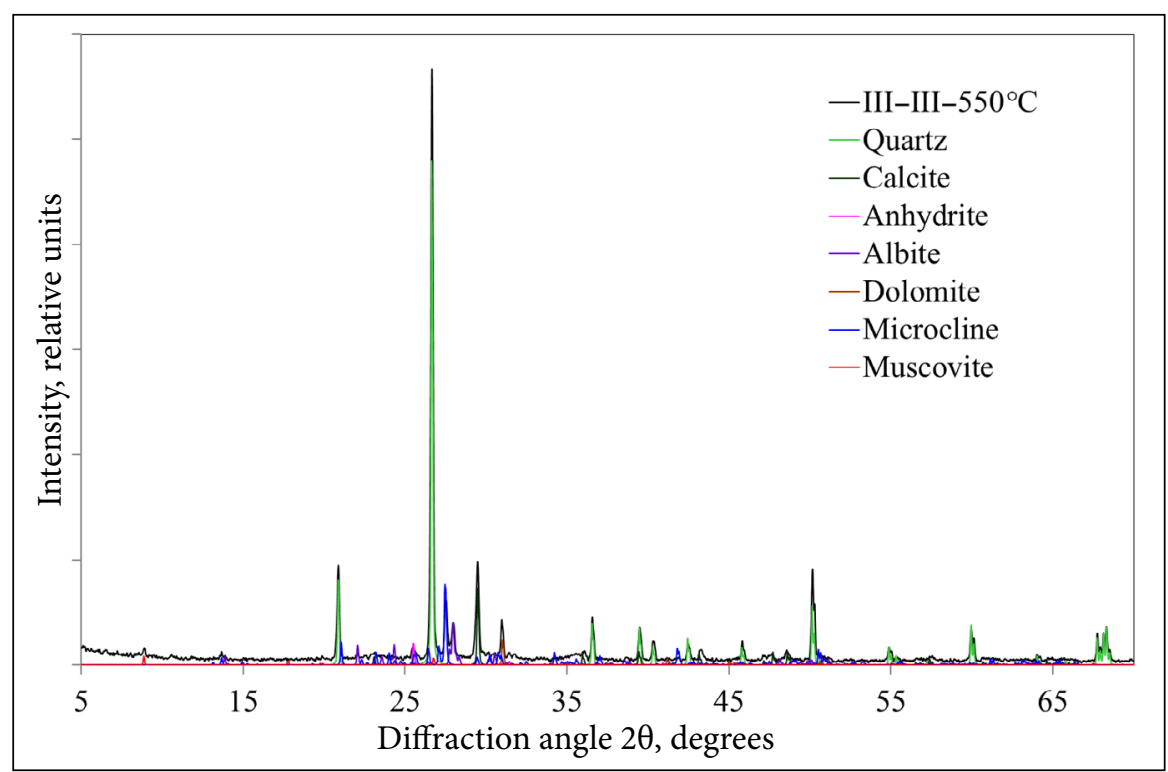

Fig. 4. XRD analysis of the heated at $550^{\circ} \mathrm{C}$ fine fraction from $3 \mathrm{~m}$ depth

At a depth of $5 \mathrm{~m}$, the same mineralogical modifications are typical, but periclase $\mathrm{MgO}$ is found instead of anhydrite. The SEM micrograph shows that the heated at $550^{\circ} \mathrm{C}$ fine fraction is composed of smaller crystals than unburned, this is mainly due to the fission of calcite and dolomite with the resulting formation of calcium and magnesium oxides (Fig. 5).

The elemental composition determined by the EDS method is showing a significant decrease of $C$ (on average $-68 \%$ ) and an increase of all other elements in comparison with the composition of an unburned fraction (Fig. 5).
The oxygen amount is increasing from 44.21 at the top to 49.64 at the bottom layer. Little carbon was found in the top layers after heating ( $<3 \mathrm{wt} . \%)$, then it suddenly increases to $17.79 \mathrm{wt} . \%$ in the 5 th layer, later again decreases to $<10 \mathrm{wt} . \%$. The amount of silicon increases in the beginning to the maximum of $25.47 \mathrm{wt} . \%$ in the third layer, later decreases to a minimum of $12.14 \mathrm{wt} . \%$ in the 5 th layer. The amount of calcium is slowly decreasing from the top. By contraries, the amount of rest elements increases from top to bottom. There is a significant amount of iron, $\sim 4-5$ wt.\% in different layers (Fig. 6). 

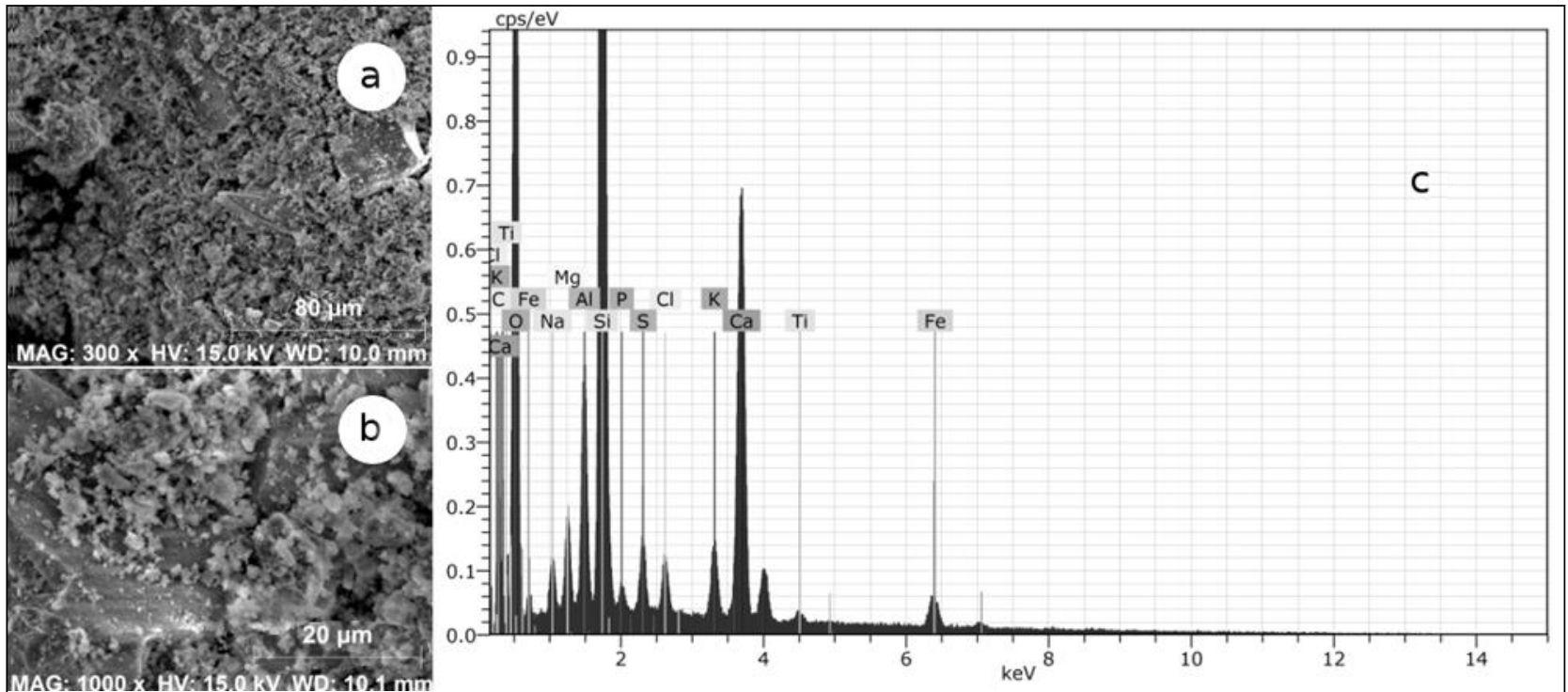

Fig. 5. SEM under magnification of 300 (a), under magnification of 1000 (b), and the EDS spectrum of the fine fraction (c) ( $3 \mathrm{~m} \mathrm{depth})$ heated at $550^{\circ} \mathrm{C}$

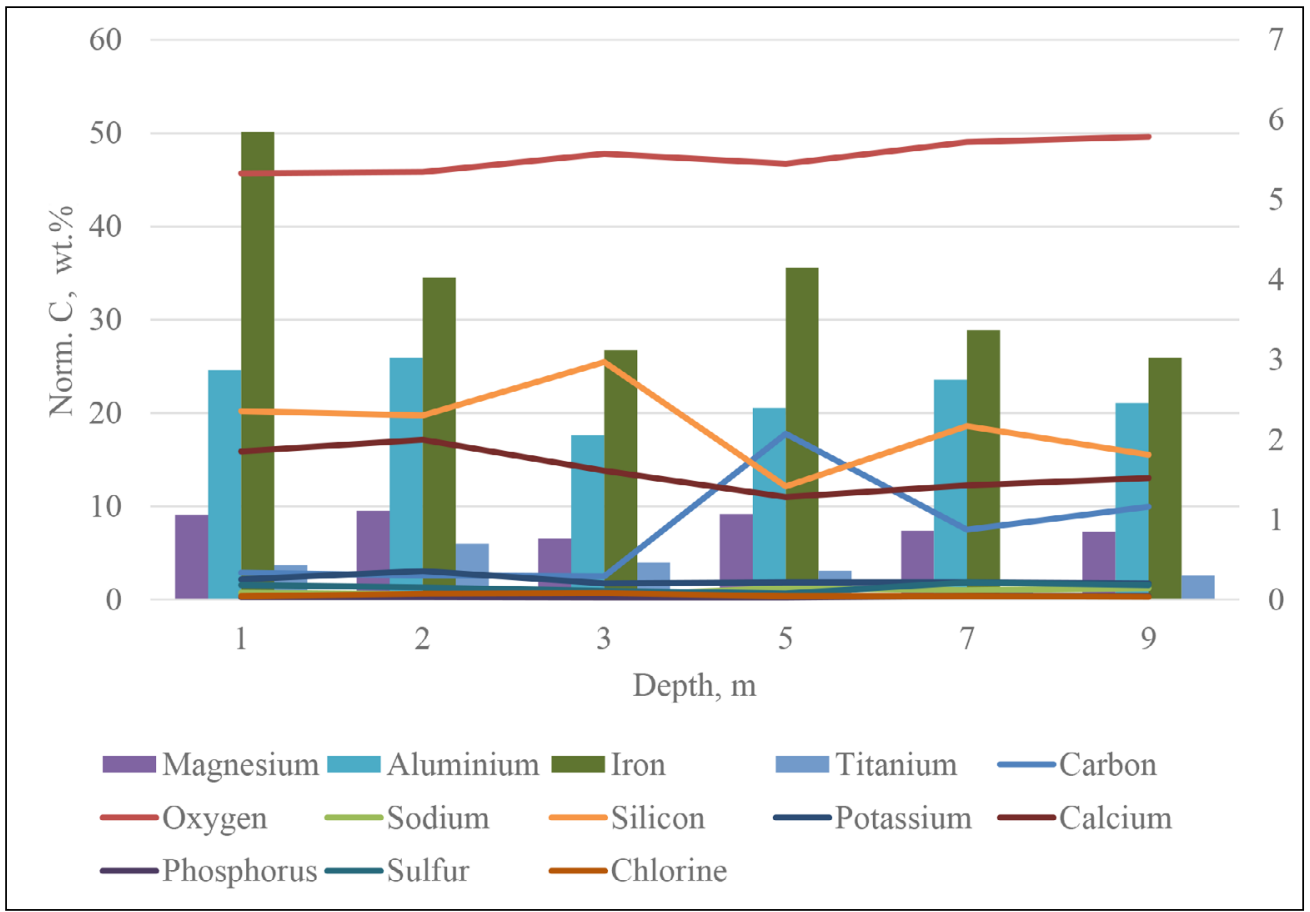

Fig. 6. Changes of the heated under $550^{\circ} \mathrm{C}$ fine fraction elemental composition in different landfill layers

\section{Heated at $850^{\circ} \mathrm{C}$ temperature fine fraction}

The same waste samples were further heated at $850^{\circ} \mathrm{C}$. Quartz $\mathrm{SiO}_{2}$, calcite $\mathrm{CaCO}_{3}$, anhydrite $\mathrm{CaSO}_{4}$, albite $\mathrm{NaAlSi}_{3} \mathrm{O}_{8}$, periclase $\mathrm{MgO}$, microcline $\mathrm{KAlSi}_{3} \mathrm{O}_{8}$ and muscovite $\mathrm{KNa}(\mathrm{Al}, \mathrm{Mg}, \mathrm{Fe})_{2}$ $\left(\mathrm{Si}_{3.1} \mathrm{Al}_{0.9}\right) \mathrm{O}_{10}(\mathrm{OH})_{2}$ were found in the heated under $850^{\circ} \mathrm{C}$ fine fraction of the landfill $(1,2$ and $3 \mathrm{~m}$ depths). At 5 and $7 \mathrm{~m}$ calcite $\mathrm{CaCO}_{3}$ and periclase $\mathrm{MgO}$ were absent, at $9 \mathrm{~m}$ depth no muscovite was found. Obviously, dolomite breaks down at this temperature and periclase $\mathrm{MgO}$ is formed (Fig. 7). The SEM micrograph shows that crystals of the heated at $850^{\circ} \mathrm{C}$ fine fraction are very similar to crystals of the heated at $550^{\circ} \mathrm{C}$ fine fraction, although the EDS analysis showed that carbonates were further decomposing, so a conclusion can be made that larger particles of carbonates are decomposing in the beginning (Fig. 8). 


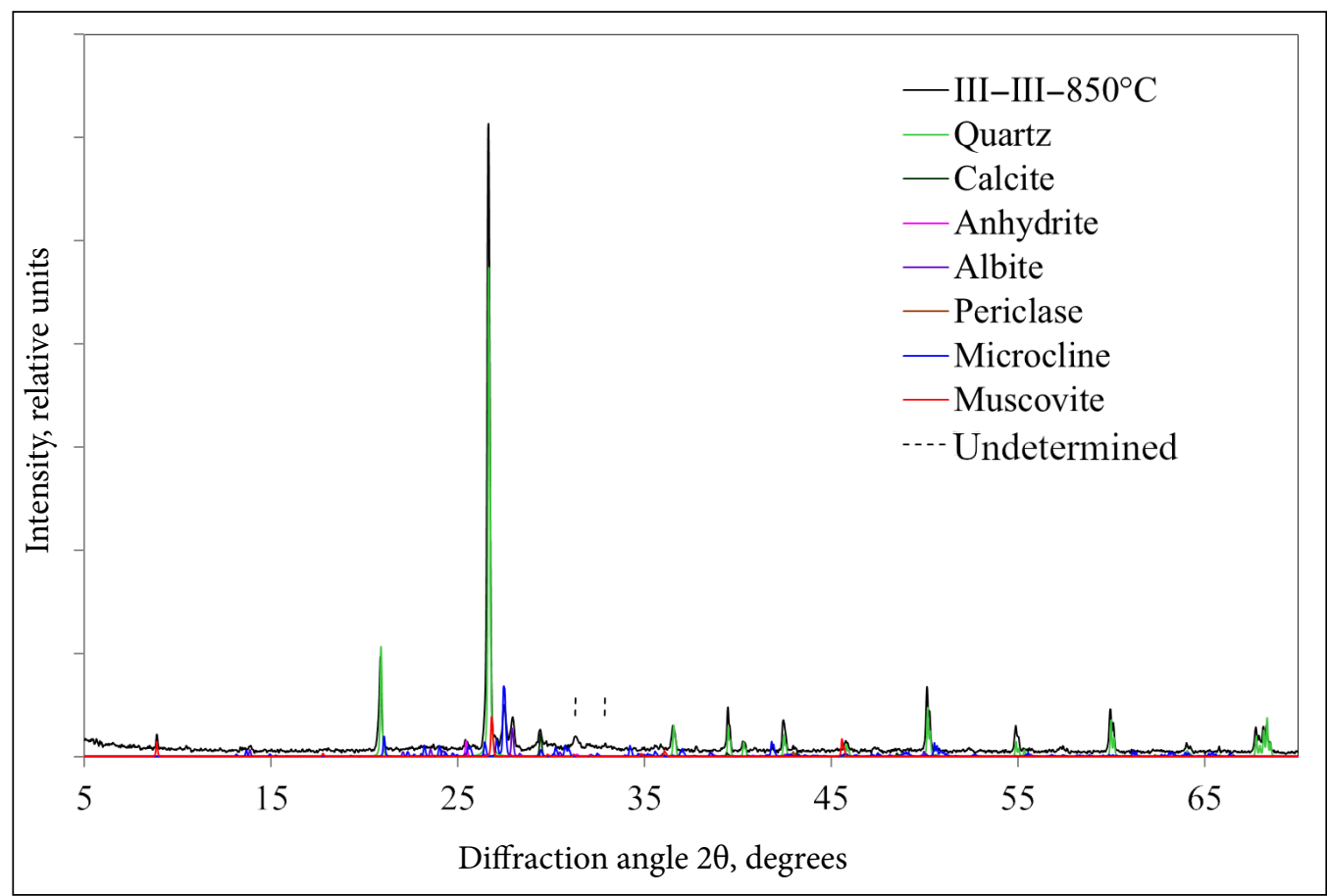

Fig. 7. XRD analysis of the heated at $850^{\circ} \mathrm{C}$ fine fraction from $3 \mathrm{~m}$ depth

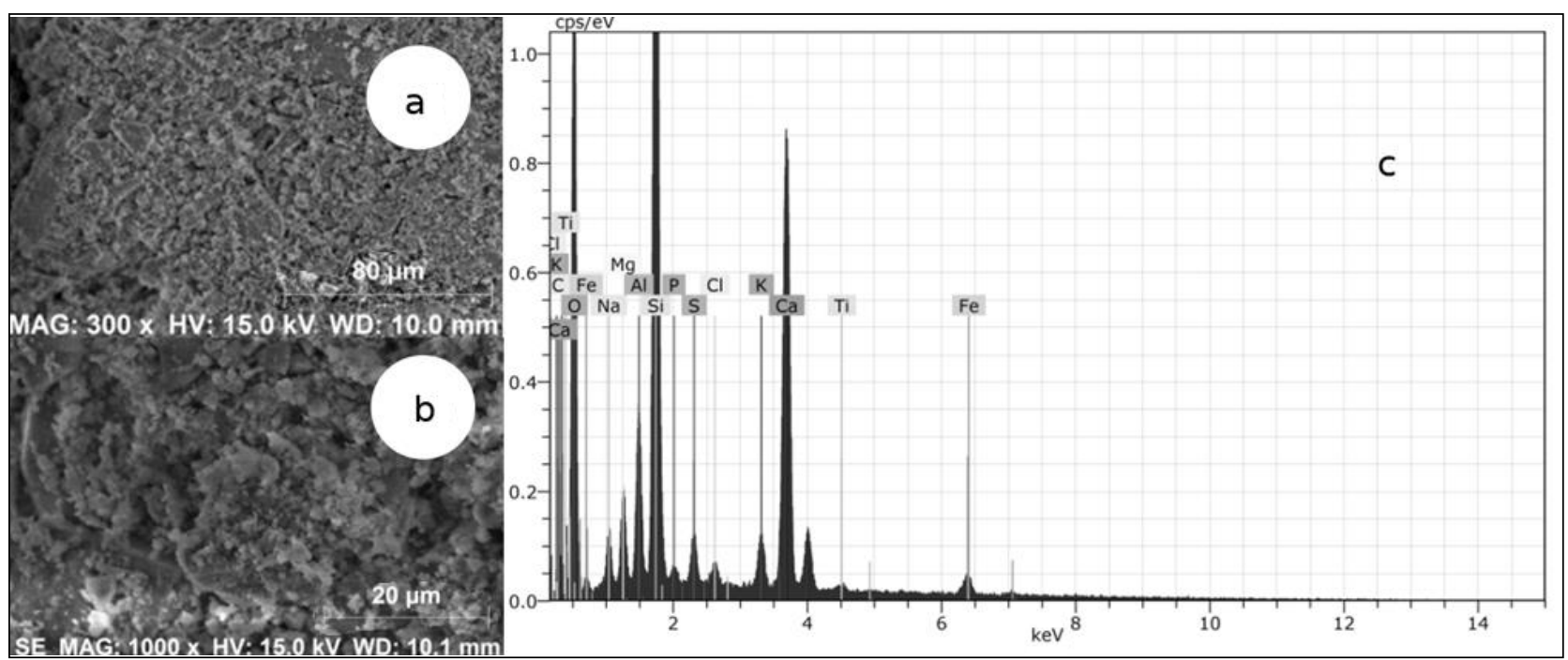

Fig. 8. SEM under magnification of 300 (a), under magnification of 1000 (b), and the EDS spectrum of the fine fraction (c) (3 m depth) heated at $850^{\circ} \mathrm{C}$

The elemental composition determined by the EDS method is showing a significant decrease of $\mathrm{C}$ (on average $-87 \%$ ) and an increase of all other elements in comparison with the composition of an unburned fraction, with the exception of $\mathrm{O}$, which virtually does not change (Fig. 8).

The oxygen amount is increasing from $43.18 \mathrm{wt} . \%$ at the top to $50.68 \mathrm{wt} . \%$ at the 5 th layer and decreasing to $47.51 \mathrm{wt} . \%$. The carbon amount is low ( $<5 \mathrm{wt} . \%$ in all layers). The amount of silicon is $\sim 20 \mathrm{wt} . \%$. The amount of calcium is $\sim 20 \mathrm{wt} . \%$ in the top layers, then decreases to $12.25 \mathrm{wt} . \%$ in the 5th layer and slightly increases at the bottom. The amount of rest elements generally increases from top to bottom (Fig. 9).

The average amounts of elements and their changes after thermal treatment are presented in the Table. 


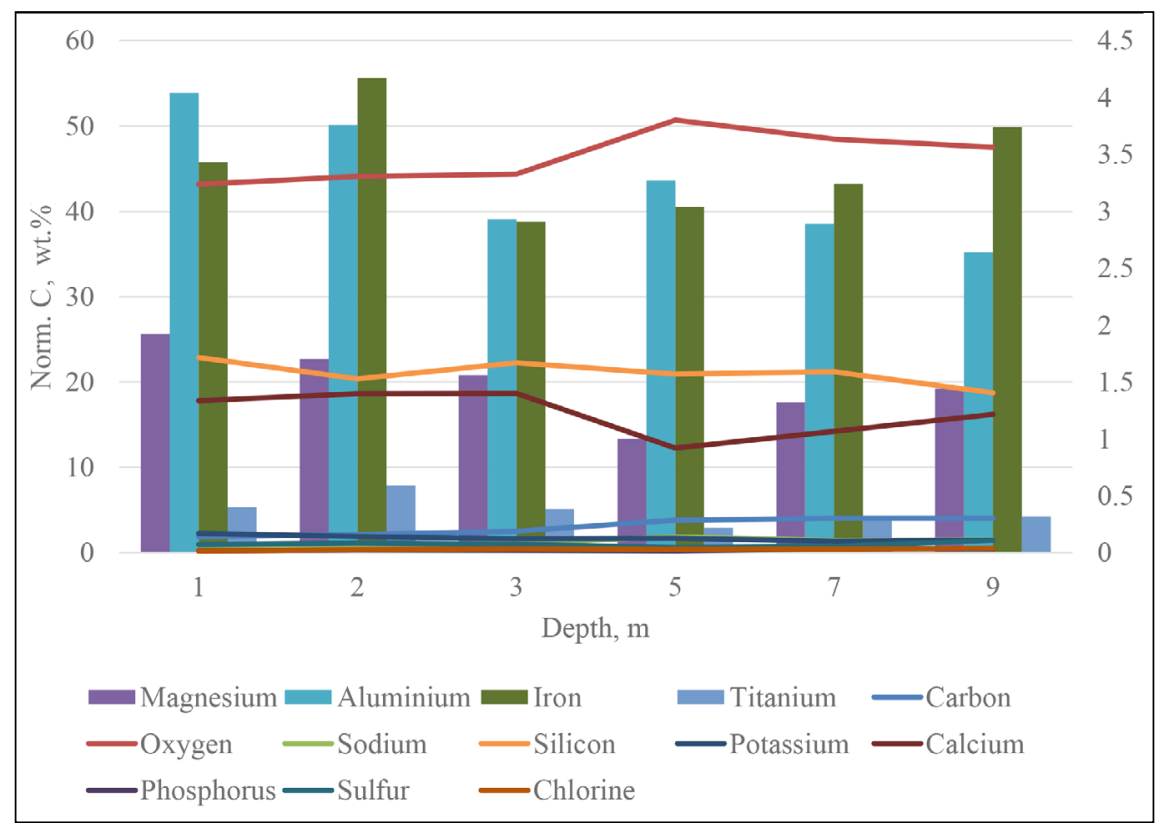

Fig. 9. Changes of the heated under $850^{\circ} \mathrm{C}$ fine fraction elemental composition in different landfill layers

\section{CONCLUSIONS}

The mineralogical composition (by XRD method) and the preliminary elemental composition (by EDS method) of the fine fraction in the Alytus Regional Landfill were investigated. With respect to the fine fraction, these and other studies were performed on unburned material and burned at $550^{\circ} \mathrm{C}$ and $850^{\circ} \mathrm{C}$.

The fine fraction of the landfill at depths of 2, 5 and $9 \mathrm{~m}$ is characterized by minerals such as quartz $\mathrm{SiO}_{2}$, calcite $\mathrm{CaCO}_{3}$, anhydrite $\mathrm{CaSO}_{4}$, albite $\mathrm{NaAlSi}_{3} \mathrm{O}_{8}$, dolomite $\mathrm{CaMg}\left(\mathrm{CO}_{3}\right)_{2}$ and microcline $\mathrm{KAlSi}_{3} \mathrm{O}_{8}$. In 1, 3 and $7 \mathrm{~m}$ depths, additionally muscovite $\mathrm{KNa}(\mathrm{Al}, \mathrm{Mg}, \mathrm{Fe})_{2}\left(\mathrm{Si}_{3.1} \mathrm{Al}_{0.9}\right) \mathrm{O}_{10}(\mathrm{OH})_{2}$ is observed. By burning at $550^{\circ} \mathrm{C}$ and $850^{\circ} \mathrm{C}$, dolomite decomposes, and the structure of periclase $\mathrm{MgO}$ is revealed.

The SEM analysis showed that after burning at $550^{\circ} \mathrm{C}$ the size of crystals significantly decreased. Change of the crystals size after burning at $850^{\circ} \mathrm{C}$ was not so big.

Using the EDS method, elements such as chlorine $\mathrm{Cl}$, phosphorus $\mathrm{P}$ and titanium Ti were identified in the fine fraction of the landfill, in addition to the above-mentioned minerals.

Based on the results of the EDS analysis, the distribution of magnesium, aluminum, iron, titanium and others in the fine fraction was determined in the landfill layers. It is not uniform and can only be explained by the change in the quantity of these elements in the waste removed in different years.

Compared to recent years (around 2008), there are little differences in the composition of different layers of landfills. As we can see that the quantities of precious metals are not high, the profitability of recovery requires a more detailed economic analysis.

\section{ACKNOWLEDGEMENTS}

This research was funded by Grant 09.3.3-LMTK-712-03-0109 from the European Union Funds Investment Program and the Lithuanian Science Council.

Received 13 May 2019 Accepted 6 June 2019

\section{References}

1. A. Bučinskas, M. Kriipsalu, G. Denafas, Sustainability, 10, 2882 (2018).

2. J. Burlakovs, Y. Jani, M. Kriipsalu, et al., J. Clean. Prod., 186, 81 (2018).

3. A. J. Calderón Márquez, P. C. Cassettari Filho, E. W. Rutkowski, R. de Lima Isaac, J. Clean. Prod., 226, 1102 (2019).

4. G. Denafas, A. Bučinskas, J. Burlakovs, et al., 4th International Conference on Sustainable Solid Waste Management: Proceedings, Limassol, Cyprus (2016). 
5. J. Mocellin, G. Mercier, J. L. Morel, P. Charbonnier, J. F. Blais, M. O. Simonnot, J. Clean. Prod., 168, 311 (2017).

6. T. J. Mönkäre, M. R. T. Palmroth, J. A. Rintala, Waste Manag., 47, 34 (2016).

7. C. L. Nassaralla, in: ed. K. H. J. Buschow, Encyclopedia of Materials: Science and Technology, p. 7938, Elsevier (2001).

8. F. Owusu-Nimo, S. Oduro-Kwarteng, H. Essandoh, F. Wayo, M. Shamudeen, Ghana. Sci. African 3, e00052 (2019).

9. T. Prechthai, C. Visvanathan, C. Cheimchaisri, Proceedings of the 2nd Joint International Conference 'Sustainable Energy and Environment (SEE 2006)', Bangkok, Thailand (2006).

10. T. P. Wagner, T. Raymond, Waste Manag., 45, 448 (2015).

11. S. Wanka, K. Münnich, K. Fricke, Waste Manag., 59, 316 (2017).

12. H. Zhang, P.-J. He, L.-M. Shao, D.-J. Lee, Environ. Sci. Technol., 42, 1586 (2008).

\section{Rugilè Kemeklytė, Algimantas Bučinskas,} Gintaras Denafas

\section{METALŲ KIEKIO TYRIMAS ALYTAUS REGIONINIO KOMUNALINIŲ ATLIEKŲ SAVARTYNO SMULKIOJOJE FRAKCIJOJE}

Santrauka

Pateikiami Alytaus regioninio sąvartyno smulkiosios atliekų frakcijos tyrimo rezultatai. Smulkioji frakcija buvo analizuojama siekiant apibūdinti ìvairių cheminių elementų kieki, naudojant skenuojančios elektroninès mikroskopijos metodą, energijos dispersijos spektroskopiją (EDS), SEM ir rentgeno difrakcijos (XRD) analizę. Aptikti šie mineralai: kvarcas $\mathrm{SiO}_{2}$, kalcitas $\mathrm{CaCO}_{3}$, anhidritas $\mathrm{CaSO}_{4}$, albitas $\mathrm{NaAlSi}_{3} \mathrm{O}_{8}$, dolomitas $\mathrm{CaMg}\left(\mathrm{CO}_{3}\right)_{2}$, mikroklinas $\mathrm{KAlSi}_{3} \mathrm{O}_{8}$, periklazas ir muskovitas $\mathrm{KNa}(\mathrm{Al}, \mathrm{Mg}, \mathrm{Fe})_{2}\left(\mathrm{Si}_{3.1}, \mathrm{Al}_{0.9}\right) \mathrm{O}_{10}(\mathrm{OH})_{2}$. Nustatytas C, O, Na, Mg, Al, Si, K, Ca, Fe, P, S, Cl, Ti cheminių elementų kiekis ir apskaičiuotas jų pokytis po kaitinimo. 